\title{
Design of decision support system for blood analysis
}

\author{
Yosep Septiana*, Dede Kurniadi, Asri Mulyani, and Wiyoga Baswardono \\ Sekolah Tinggi Teknologi Garut, Department of Informatics, Jl. Mayor Syamsu No. 1, Garut 44151, Indonesia
}

\begin{abstract}
Blood analysis is a medical check by identifying blood that gives an explanation of health and is one way to detect certain conditions. Blood type determination is one of the scopes in a blood analysis. This research aims to design a decision support system for blood analysis Solver-oriented for the determination of blood type with $\mathrm{ABO}$ system (blood type system A, B, AB, and O) and Rhesus based on Immunohematology Concept theory. The system development method used is Big-Bang Model, with an object-oriented design approach. The result of this research is a software that can be used by health laboratories to assist the process of determining the blood type. With the use of decision support systems information technology-based, the results of the analysis of blood group determination will be more accurate to minimize the occurrence of errors in the determination of blood type.
\end{abstract}

\section{Introduction}

Blood analysis is health check to evaluate the internal environment of the body that is identified through blood barrels [1]. Blood analysis is a qualitative analysis of blood using simple procedures by taking droplets of blood from patient's finger (the examined blood is still alive) to get an accurate and fast results examination of blood about how the blood works in the patient's body [2]. The determination of blood type is one of the scopes in a blood analysis. It is important to acknowledge the blood types because it will be helpful during the blood transfusions and identification of off-springs. The test to determine blood type is done through laboratory test to blood sample by doing reaction between samples of blood tested with antisera fluid, then do the observation of the physical change of blood sample better known as observation of agglutination reaction [3]. The combination of resulting reaction will determine certain blood type [4]. Testing to determine the blood type has to be done meticulously and accurately. Error in the reading type of blood can cause a very serious issue, for example, error in the process of blood transfusion will be fatal because it is concerned with people's lives. Also, error in identification offspring will cause a social impact [5]. Testing and observation to determine the blood type must be done by an experienced and competent person because the accuracy of data achieved still relies on the ability, thoroughness, and memory of the testers. Facts on the ground, researchers, researched one of the health laboratories, in conducting the blood type test after through the testing and observation process, a process in determining the blood types were taken. The determination process of blood types result was done several times by some laboratory officers to avoid human error, which is, an error in the last procedure of determining the blood types. It could happen because sometimes testers lost the focus that could result in them forgetting or making mistakes about the classification pattern system of blood type.

Development of technology has helped a human in improving quality of life [6], one of the forms is the information technology [7]. The implementation of technology in information to find solutions to a problem is not structured well, and it is usually be put into a Decision Support System (DSS). DSS is the part of an information system for supporting the decision for decision making. Refers to several research, an information system has a high capability in decision making, the system has an accurate data accessibility and efficient run-time [8], high accuracy [9], and to support a proper decision [10], low cost [11], extended accessibility [12], intensify user knowledge, increase productivity [13], provide a better data and information [14], and in the certain cases are potentially used as data storage [15]. DSS is used to make a problem-solving decision accurately and quickly, of course, the resulting information is obtained from data that has been processed in a relevant manner [16]. DSS is a computer-based system created using data and models with the aim is to help decision making problem solving that is not structured $[17,18]$. DSS is a software that can analyze data that combines human intellectual resources with the help of a computer that aims to improve the quality, speed and accuracy in decision making $[19,20]$.

Based on the above description, the researcher formulates the problem to be discussed: how to design the blood analysis application program as a DSS of Solveroriented blood type determination. Researchers limit it on the design of blood analysis application program that includes the blood analysis application program as DSS of Solver-oriented blood types determination with $\mathrm{ABO}$ system (system of blood classification $\mathrm{A}, \mathrm{B}, \mathrm{AB}$, and $\mathrm{O}$ ) and Rhesus based on Immunohematology Concept theory by Austrian Karl Landsteiner [21]. The purpose of this

* Corresponding author: yseptiana@sttgarut.ac.id 
study is to design a live blood analysis application program as DSS Solver-oriented blood type classifications, which is expected that by the use of information technology-based DSS, the result of blood type classification will be more accurate.

\section{Methodology}

\subsection{System Development Method}

The system development method used is Big-Bang Model. Where researchers can determine the steps of designing the system with more flexibility in accordance with the needs in the design process.

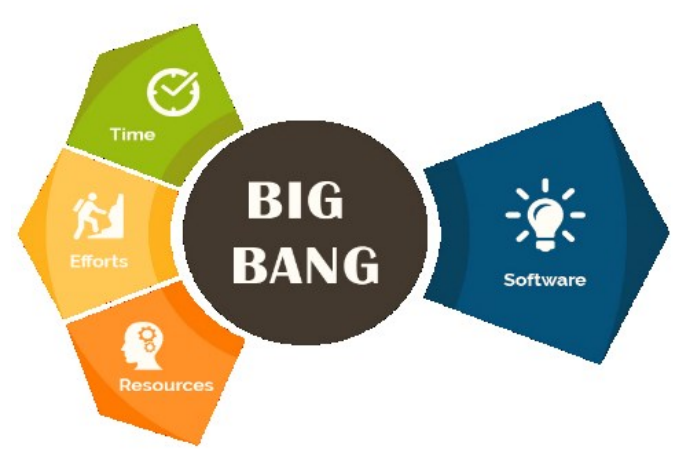

Fig. 1. Big-Bang Model [22].

Design approach used is oriented design approach so that in data modeling, researcher use the use case diagram model [23]. The system design framework in the research is presented in Figure 2.

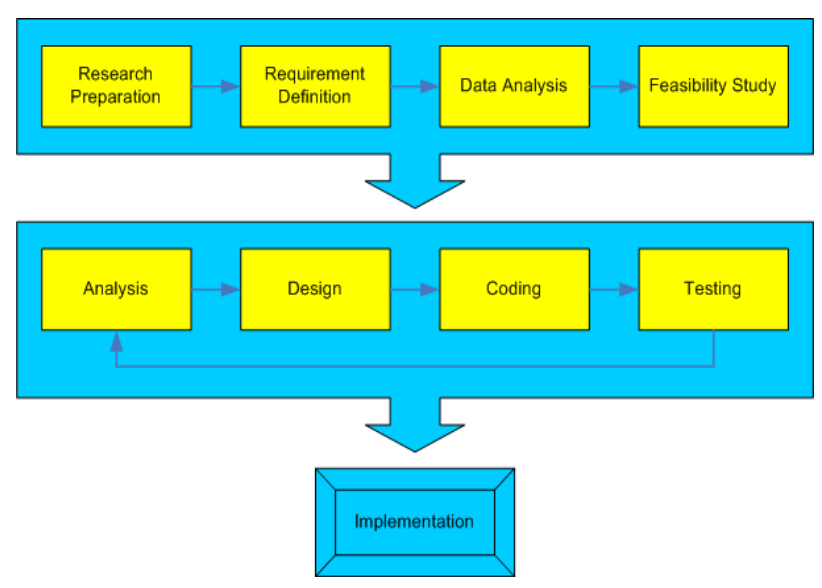

Fig. 2. The framework of System Design.

\subsection{Data Source}

Sources of data that researchers use is from the printed media in the form of reference books (general references), articles, and scientific journals, as well as sources of data derived from non-printed media, in the form of data obtained directly from sources at the time of interview [24].

\subsection{Data Collection Technique}

The data collection techniques used, are as follows: Observation directly examines the procedure of blood type classification at INTI Laboratory Clinic Garut; Interview, conduction Q\&A directly with interested / related parties (in this case, the researchers interviewed with the head of the clinic laboratory, laboratory personnel, and INTI laboratory Clinic Garut); and Literature Study (taking references from books and writings of scientific papers related to research conducted).

\section{Result and Discussion}

\subsection{Analysis}

The analysis is an early stage to determine the problems that occur, thus providing an overview of the system requirements of the design that will be done [25]. This stage should be done correctly so that the result of system design can be used optimally [26].

Here is the SWOT analysis (Strong, Weakness, Opportunity dan Threat) from the designed blood-type classifications DSS:

1. Strong (Strength), provides convenience in the procedure of classifying the blood types and easy to use by users (user-friendly).

2. Weakness only manages the data of blood-types classification and standard interface feature.

3. Opportunity, the designed system can be developed for more completed coverage of the system and can be one of the ways out to streamline the procedure of blood-type classification.

4. Threat

Similar user-friendly system.

\subsection{Design}

At this stage, the elite uses an object-oriented design approach that includes modeling system, interface design, and system operational environments.

\subsubsection{Modeling System}

The modeling system can be designed, illustrated through the use case diagram (Figure 3 ).

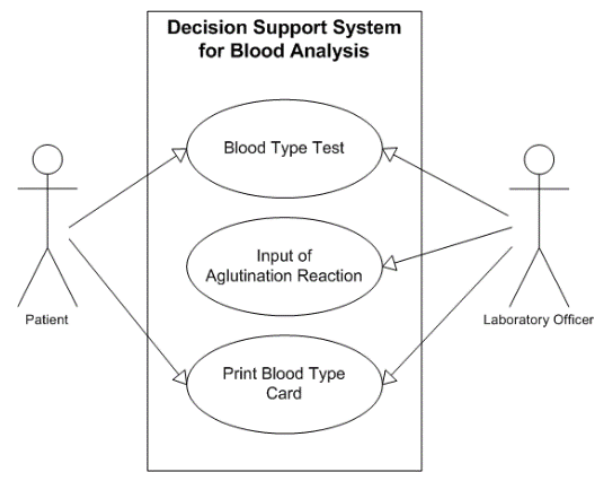

Fig. 3. Modeling System. 


\subsubsection{Interface Design}

The interface display of the blood type classification DSS is presented in Figure 4.

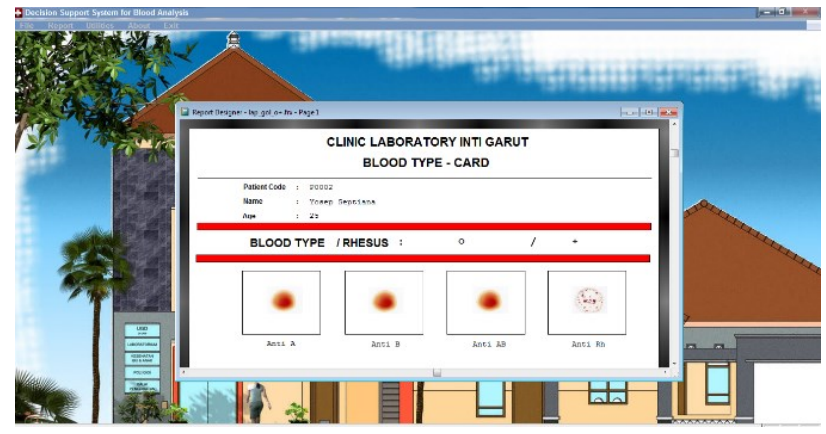

Fig. 4. Interface Display.

\subsubsection{Operational System Environment}

1. Hardware and Software Specifications

The minimum hardware and software specifications used to design the system are as follows:

a. Hardware specifications used: Pentium-class Processor, 64 MB of RAM; Hard Disc capacity, $165 \mathrm{MB}$

b. Software specifications used Microsoft Server 2003 and Microsoft Visual FoxPro 9.

2. Quality Characteristics

Characteristics of systems designed to have standardization as follows: the result of the system us in the form of a stand-alone file (executable); the designed system should be able to accommodate data processing of blood type classification, and the system designed is the first version (prototype 1) so that for the future can be used as a blueprint for the next design.

\subsection{Coding}

In the designed program there are several program specifications (coding) for some program modules, which are as follows: program module user login and main menu form; program module patient and blood type data input form; and program module print of laboratory tests and blood card-type printing form;

\subsection{Testing}

System testing is performed program module as well as the whole system; the purpose is to ensure that the system is designed to have a quality that corresponds to the representation of the requirements specification at the time of system analysis, design and encoding stages [27]. The testing method used is black-box testing. Testing is done by running or executing unit or program module and then conduction an observation about the suitability between data entered, whether it has resulted in output in accordance, with the functionality of the system designed. The aim is to look for errors in the data structure, interface, initialization and final destination, as well as the function of the designed program modules [28].

\section{Conclusion}

Based on the results of research on the design of DSS for blood analysis, can be accurate information, effective and efficient so it can assist in decision determining blood type. What can be done by this DSS is as follows: speed in data processing, such as patient data entry, calculation of blood type determination, and reporting of patient and blood type data; efficiency in searching, recording and entering patient data and blood type so that there is an increase in the health services provided, and the results of patient and blood group data report required can be obtained/accessed easily DSS determination of blood type designed to help the performance of laboratory officers in deciding detection or determination of blood type more accurately.

\section{References}

1. L. Vitetta, H. Sali, J. Burke, L. Mrazek, F. Cortizo and A. Sali, "The Live Blood Analy8i6 Technique," academia.edu, vol. 1, pp. 1-6, (2005)

2. K. Lawonn, S. Glaßer, A. Vilanova, B. Preim and T. Isenberg, "Occlusion-free blood flow animation with wall thickness visualization," IEEE transactions on visualization and computer graphics, vol. 22, no. 1, pp. 728-737, (2016)

3. G. Stussi, K. Huggel, H. U. Lutz, U. Schanz, R. Rieben and J. D. Seebach, "Isotype-specific detection of $\mathrm{ABO}$ blood group antibodies using a novel flow cytometric method," British journal of haematology, vol. 130, no. 6, pp. 954-963, (2005)

4. E. Danese, G. Lippi and M. Montagnana, "Red blood cell distribution width and cardiovascular diseases," Journal of thoracic disease, vol. 7, no. 10, p. E402, (2015)

5. C. M. Cserti and W. H. Dzik, "The ABO blood group system and Plasmodium falciparum malaria," Blood, vol. 110, no. 7, pp. 2250-2258, (2017)

6. M. A. Ramdhani, H. Aulawi, A. Ikhwana and Y. Mauluddin, "Model of Green Technology Adaptation in Small and Medium-Sized Tannery Industry," Journal of Engineering and Applied Sciences, vol. 12, no. 4, pp. 954-962, (2017)

7. A. Pamoragung, K. Suryadi and M. A. Ramdhani, "Enhancing the Implementation of e-Government in Indonesia Through the High-Quality of Virtual Community and Knowledge Portal," in 6th European Conference on e-Government, Marburg, (2006)

8. C. Slamet, A. Rahman, A. Sutedi, W. Darmalaksana, M. A. Ramdhani and D. S. Maylawati, "Social Media-Based Identifier for Natural Disaster," IOP Conference Series: Materials Science and Engineering, vol. 288, no. 2017, p. 012039, (2018) 
9. C. Slamet, R. Andrian, D. S. Maylawati, Suhendar, W. Darmalaksana and M. A. Ramdhani, "Web Scraping and Naïve Bayes Classification for Job Search Engine," IOP Conference Series: Materials Science and Engineering, vol. 288, no. 2017, p. 012038, (2018)

10. Y. A. Gerhana, W. B. Zulfikar, A. H. Ramdani and M. A. Ramdhani, "Implementation of Nearest Neighbor using HSV to Identify Skin Disease," IOP Conference Series: Materials Science and Engineering, vol. 288, no. 2017, p. 012153, (2018)

11. A. Rahman, C. Slamet, W. Darmalaksana, Y. A. Gerhana and M. A. Ramdhani, "Expert System for Deciding a Solution of Mechanical Failure in a Car using Case-based Reasoning," IOP Conference Series: Materials Science and Engineering, vol. 288, no. 2017, p. 012011, (2018)

12. C. Slamet, A. Rahman, M. A. Ramdhani and W. Darmalaksana, "Clustering the Verses of the Holy Qur'an using K-Means Algorithm," Asian Journal of Information Technology, vol. 15, no. 24, pp. 5159-5162, (2016)

13. W. B. Zulfikar, Jumadi, P. K. Prasetyo and M. A. Ramdhani, "Implementation of Mamdani Fuzzy Method in Employee Promotion System," IOP Conference Series: Materials Science and Engineering, vol. 288, no. 2017, p. 012147, (2018)

14. D. S. Maylawati, M. A. Ramdhani, A. Rahman and W. Darmalaksana, "Incremental technique with set of frequent word item sets for mining large Indonesian text data," in International Conference on Cyber and IT Service Management, Denpasar, (2017)

15. A. Taofik, N. Ismail, Y. A. Gerhana, K. Komarujaman and M. A. Ramdhani, "Design of Smart System to Detect Ripeness of Tomato and Chili with New Approach in Data Acquisition," IOP Conference Series: Materials Science and Engineering, vol. 288, no. 2017, p. 012018, (2018)

16. D. J. Power, R. Sharda and F. Burstein, Decision support systems, (John Wiley \& Sons, 2015)

17. K. Suryadi and M. A. Ramdhani, Sistem Pendukung Keputusan, (Bandung: Remaja Rosdakarya, 2002)

18. R. C. M. Yam, P. W. Tse, L. Li and P. Tu, "Intelligent predictive decision support system for condition-based maintenance," The International Journal of Advanced Manufacturing Technology, vol. 17, no. 5, pp. 383-391, (2011)

19. E. Sofiah and Y. Septiana, "Sistem Pendukung Keputusan Feasibility Study untuk Menilai Kelayakan Sebuah Bisnis," Jurnal Wawasan Ilmiah, vol. 8, no. 1, pp. 1-7, (2017)

20. Y. Septiana, D. Kurniadi and A. Mulyani, "Perancangan Program Aplikasi Faraidh sebagai Sistem Pendukung Keputusan Pembagian Harta Waris Berorientasi Solver," Jurnal Algoritma, vol. 14, no. 2, pp. 474-480, (2017)
21. H. P. Schwarz and F. Dorner, "Karl Landsteiner and his major contributions to haematology," British Journal of Haematology, vol. 121, no. 4, pp. 556565, (2003)

22. R. Arora and N. Arora, "Analysis of SDLC Models," International Journal of Current Engineering and Technology, vol. 1, no. 1, pp. 1-6, (2016)

23. D. Kurniadi, S. Sasmoko, H. L. H. S. Warnars and F. L. Gaol, "Software size measurement of student information terminal with use case point," in 2017 IEEE International Conference on Cybernetics and Computational Intelligence (CyberneticsCom), (2017)

24. N. S. Sukmadinata, Metode penelitian, (Bandung: PT. Remaja Rosda Karya, 2007)

25. Y. Septiana, "Perencanaan Strategis Sistem Informasi dengan Pendekatan Ward and Peppard Model," Jurnal Wawasan Ilmiah, vol. 8, no. 1, pp. 8-24, (2017)

26. J. D. Glover, M. S. Sarma and T. Overbye, "Power System Analysis \& Design, SI Version," Cengage Learning, (2012)

27. R. Kuhn, R. Kacker, Y. Lei and J. Hunter, "Combinatorial software testing," Computer, vol. 42, no. 8, (2009)

28. C. Henard, M. Papadakis, M. Harman, Y. Jia and Y. Le Traon, "Comparing white-box and black-box test prioritization," In Software Engineering (ICSE), 2016 IEEE/ACM 38th International Conference, pp. 523-534, (2016) 